\title{
Overlapping International Instruments for Enforcement of Insolvency Judgments: Undermining or Strengthening Universalism?
}

\author{
Irit Mevorach ${ }^{1,2}$ \\ Published online: 8 February 2021 \\ (c) The Author(s) 2021
}

\begin{abstract}
In recent years modified universalism has emerged as the normative framework for governing international insolvency. Yet, divergences from the norm, specifically regarding the enforcement of insolvency judgments, have also been apparent when the main global instrument for cross-border insolvency has been interpreted too narrowly as not providing the grounds for enforcing judgments emanating from main insolvency proceedings. This drawback cannot be overcome using general private international law instruments as they exclude insolvency from their scope. Thus, a new instrument - a model law on insolvency judgments- has been developed. The article analyses the model law on insolvency judgments against the backdrop of the existing cross-border insolvency regime. Specifically, the article asks whether overlaps and inconsistencies between the international instruments can undermine universalism. The finding is mixed. It is shown that the model law on insolvency judgments does add vigour to the cross-border insolvency system where the requirement to enforce and the way to seek enforcement of insolvency judgments is explicit and clear. The instrument should, therefore, be adopted widely. At the same time, ambiguities concerning refusal grounds based on proper jurisdiction and inconsistencies with the wider regime could undermine the system. Consequently, the article considers different ways of implementing the model law and using it in future cases, with the aim of maximizing its potential, including in view of further developments concerning enterprise groups and choice of law.
\end{abstract}

Keywords Private international law $\cdot$ Cross-border insolvency $\cdot$ Modified universalism $\cdot$ Enforcement of judgments $\cdot$ Model law

\footnotetext{
The author advises the UK delegation at UNCITRAL, Working Group V (Insolvency) (and previously represented the World Bank), which drafted the instruments discussed in this article. However, the opinions expressed in this article are solely the author's and do not necessarily represent the views of these groups or organizations.
}

Irit Mevorach

Irit.Mevorach@nottingham.ac.uk

Extended author information available on the last page of the article 


\section{Introduction}

The collapse or distress of businesses operating across-borders can affect multiple stakeholders, including banks, trade creditors, employees, shareholders, and even entire economies. Conflict between laws, duplication of processes, lack of cooperation between courts or insolvency professionals and the disintegration of the failed business' administration exacerbate the damage.

The norm of 'modified universalism' ${ }^{\text {' }}$ requires a global approach to multinational default, which can resolve conflicts and result in optimal insolvency solutions. The norm is reflected in the main global instrument for cross-border insolvency-the United Nations Commission on International Trade Law (UNCITRAL) Model Law on Cross-Border Insolvency (MLCBI) of $1997 .^{2}$ But the application of the MLCBI exposed a gap or uncertainty regarding its application to the enforcement of judgments, highlighted most impactfully by the UK Supreme Court in Rubin v. Eurofinance where the UK court refused to enforce a judgment emanating from the main insolvency process. ${ }^{3}$ At the same time, insolvency, including the enforcement of insolvency judgments, is excluded from general private international instruments for commercial matters. ${ }^{4}$

UNCITRAL decided to step into the void and develop a new instrument, which was finally adopted by the organization in 2018 as a Model Law on the Recognition and Enforcement of Insolvency-Related Judgments (MLIJ). ${ }^{5}$ The MLIJ has been quite well-received and considered by commentators a significant improvement of the current position: "[s]ubject to any shortcomings that become apparent after its implementation, the Judgments Model Law appears to be a sensible, largely uncontroversial adjunct to the Cross-Border Model Law; ${ }^{6}$ it is 'undoubtedly a potentially significant step forward in international co-operation'. ${ }^{7}$ Now, countries need to consider whether to enact the MLIJ and if so how to embed it in local law. Adoption may take time, as it is common for several years to pass before countries start

\footnotetext{
1 The label 'modified universalism' was introduced by Professor Westbrook (Westbrook 1991, p 517).

2 United Nations Commission on International Trade Law, UNCITRAL Model Law on Cross-Border Insolvency (1997) with Guide to Enactment and Interpretation (2013) (https://www.uncitral.org/pdf/engli sh/texts/insolven/1997-Model-Law-Insol-2013-Guide-Enactment-e.pdf).

3 Rubin v. Eurofinance SA [2012] UKSC 46, [2013] 1 AC 236.

4 Insolvency is excluded from the Hague Convention on the Recognition and Enforcement of Foreign Judgments of 2 July 2019 (https://www.hcch.net/en/instruments/conventions/full-text/?cid=137) (see Art. 2(1)(e)); Bankruptcy judgments are also excluded from the EU regime for enforcement of judgments in civil and commercial matters (Regulation (EU) No. 1215/2012 of the European Parliament and of the Council of 12 December 2012 on the jurisdiction and the recognition and enforcement of judgments in civil and commercial matters [2012] OJ L 351/1). Bankruptcy matters were also excluded from the Hague Convention of 1 February 1971 on the Recognition and Enforcement of Foreign Judgments in Civil and Commercial Matters and from the Convention of 30 June 2005 on Choice of Court Agreements. See also Mevorach and Walters (2020), p 4.

5 UNCITRAL Model Law on Recognition and Enforcement of Insolvency-Related Judgments with Guide to Enactment (United Nations, Vienna 2019) (https://uncitral.un.org/sites/uncitral.un.org/files/ media-documents/uncitral/en/ml_recognition_gte_e.pdf).

${ }^{6}$ Hawthorn and Young (2018), p 197.

7 Moss (2019), p 23.
} 
enacting domestic laws on the basis of a model law. ${ }^{8}$ The global pandemic, and in the UK the Brexit process as well, may cause further delays.

When countries do, however, contemplate adoption of the new instrument, it is anticipated that this will generate a policy and legislative discussion. The MLIJ project took place against a compound background of diverse interpretations of the existing framework and mixed aims informed it. Not all countries viewed the MLCBI as excluding judgments, and so the MLCBI and the MLIJ to some extent overlap. It may be questioned whether the MLIJ really adds to the regime and should be enacted. Where it is considered helpful, there are also questions about potential inconsistencies. Adoption of the MLIJ may also be an occasion to consider adoption of the MLCBI by countries who have not already done so before, and in the process could question whether the instruments should be enacted separately or should be merged. Countries may also consider adoption of the new model law for enterprise group insolvency (finalised a year after the MLIJ), ${ }^{9}$ and again this may raise questions of compatibility between the instruments. The work of UNCITRAL on choice of law may also impact the MLIJ. ${ }^{10}$ If the MLIJ is adopted, issues will likely arise concerning its application and interpretation (and the potential interaction with other model laws as enacted in the country), in individual cases. The delays caused by external forces and political circumstances can provide a breathing space to reflect on the regime and analyse the MLIJ thoroughly and in context, so that when the time comes, it is implemented in the most effective manner.

This article contributes to this awaited debate, adoption, and application process by considering the issue of the enforcement of insolvency judgments in the context of the cross-border insolvency framework and its underlying norm of modified universalism. The aim of this article is ultimately practical: to encourage wide adoption of uniform rules concerning the enforcement of insolvency judgments, and application in a way that can promote fair and efficient results in international insolvencies. The article explores alternative ways of implementation, considering the different ex ante positions of countries concerning the issue of enforcement of judgments in the context of international insolvency, also suggesting how the MLIJ can work and can be used in different circumstances.

The article is structured as follows: the next section (Sect. 2) overviews the norm of modified universalism, specifically its application to the enforcement of insolvency judgments. Section 3 shows how modified universalism is reflected in the original model law on cross-border insolvency, the MLCBI, but how the MLCBI has been interpreted by some countries narrowly, concerning the enforcement of judgments. Section 4 provides a detailed overview of the MLIJ and its key features, showing how it was also informed by general private international law instruments. Section 5 discusses the new regime for the enforcement of insolvency judgments,

\footnotetext{
${ }^{8}$ For example, the MLCBI was adopted by the Commission in 1997 but countries began adopting it only in the early 2000s (see https://uncitral.un.org/en/texts/insolvency/modellaw/cross-border_insolvency /status).

9 See text to $n .163$ below.

10 See n. 175 below.
} 
comparing the MLIJ and the MLCBI, highlighting overlaps and inconsistencies. Section 6 provides concrete suggestions for implementing and applying the MLIJ, and in doing so considers different alternatives as well as implications of newer developments concerning enterprise groups and choice of law rules. Section 7 concludes.

\section{Enforcement of Judgments Under Modified Universalism}

The private international law of insolvency has been evolving as a unique system. Insolvency is generally excluded from international instruments on private international law because of its special character and connectedness with public policy concerns. ${ }^{11}$ Modified universalism is to date the dominant approach for addressing cross-border insolvencies. ${ }^{12}$ It adapts (pure) universalism, which prescribes a utopic vision of a single law/single forum system for international insolvencies, ${ }^{13}$ to the reality of a world divided into different legal systems and a myriad of business structures. Thus, modified universalism seeks to achieve global collective processes with optimal levels of centralization of insolvency proceedings. ${ }^{14}$

Modified universalism is much more focused than notions such as 'international comity' or assistance, which can be achieved, for example, by opening local parallel proceedings and applying domestic laws. ${ }^{15}$ Comity generally refers to the established tradition among judges within the common law legal tradition to cooperate and assist foreign jurisdictions. ${ }^{16}$ It encourages judicial deference and cooperation. ${ }^{17}$ But notwithstanding the prominent status of the concept of international comity, ${ }^{18}$ it is considered quite vague and uncertain and is understood differently in different systems. ${ }^{19}$

\footnotetext{
${ }^{11}$ See $\mathrm{n} .4$ above.

${ }^{12}$ See Mevorach (2018a), pp 32-38; Mevorach, (2018b), p 1403.

${ }^{13}$ See Westbrook (2000), pp 2293-2294. Pure universalism is contrasted with territorialism, which would confine the effects of insolvency proceedings to the jurisdiction where proceedings are opened (see LoPucki 2000, p 2218).

${ }^{14}$ See also 'cooperative territorialism' where each country would administer the assets located within its own borders as separate estates but may conclude agreements that allow for mutually beneficial cooperation (LoPucki 1999, pp 742-743).

${ }^{15}$ Cf. Re OJSC International Bank of Azerbaijan [2018] EWCA Civ. 2802, para. 79: '[...] If it is desired to go further, and bind foreign creditors who would not otherwise be bound, the long-standing practice in international restructurings of the present type has been to apply for parallel schemes of arrangement in other jurisdictions [...]'. See also Walters (2019), p 47 (noting the competing versions of modified universalism).

${ }^{16}$ Fletcher (2005), p 17.

${ }^{17}$ Westbrook (2019), p 6 ('Comity addresses judicial deference/cooperation in light of a foreign proceeding $[\ldots]$ Traditional comity relates to deference to other courts in the same case $[\ldots]$ ').

${ }^{18}$ See also ibid. (referring to a "ubiquitous doctrine of "comity").

19 Mevorach (2018a), pp 99-100. Comity has also been exercised by a rather limited number of countries and has not been widely practiced (Paul 1991, pp 27-44). See also Westbrook (2019), p 7 (referring to 'the murky doctrine of comity').
} 
Under modified universalism, deference demanded of ancillary courts flows more specifically from the designation of a main court within a body of law that seeks to centralize decision-making. These proceedings should encompass all the business' assets and all its stakeholders, depending on what is most efficient in the circumstances-'[T]he essence of modified universalism is that "bankruptcy proceedings [...] should be unitary and universal, recognized internationally and effective in respect of all the bankrupt's assets". ${ }^{20}$ Modified universalism aims to promote fairness and an efficient system through such optimal levels of centralization that can lead to global solutions, which benefit stakeholders wherever they are located. It can increase returns to creditors as well as the likelihood of saving viable debtors. If a business spans across more than one country, it and its stakeholders in any country would benefit from an approach that minimizes the costs of multiple proceedings. Centralization of the process can keep the business together and prevent its breakup in proceedings in multiple forums and allows the conceiving of solutions that maximize the business and its assets' potential. ${ }^{21}$

To achieve this, the central process and its judgments and orders should have effect in other countries where the debtor has presence or where stakeholders are located. ${ }^{22}$ Judgments related to the insolvency proceeding include those linked to the estate, such as avoidance of pre-insolvency transactions, orders concerning the recovery of assets and pursuit of claims by the insolvency representative, or contributions from directors, as well as decisions to approve plans, complete a process and discharge the debtor. ${ }^{23}$ In this regard, universal enforcement relies not just on comity (i.e. a discretionary deference to foreign proceedings and cooperation) but on consistent and mandated support for a global central process. Recognition and enforcement of the various orders and judgments originating in the central proceeding may need to be speedy. In any event, it should not be conditioned by the similarities of the laws of the host and home country.

Modified universalism acknowledges that more than one process may be opened because that could be more efficient (for example in mega cases spanning multiple jurisdictions and time-zones), in which case several laws may apply. It also acknowledges differences between regions and systems, and the ultimate responsibility of sovereign states for their constituencies. This requires a degree of local control and a possibility that support for a main process may be denied. Yet, recognition and support should be refused in limited circumstances, essentially to uphold fundamental public policies and ensure that creditors are adequately protected. Countries should not be required to defer to a foreign system that falls below international standards (i.e. where it does not follow a collective system, which treats creditors equitably), and should be able to protect creditors against discrimination (i.e. the unfavourable treatment of local creditors, whose claims would otherwise be similarly ranked under foreign and local law, in the foreign proceeding) and against breaches of due

\footnotetext{
${ }^{20}$ In re Agrokor d.d. et al 591 BR 163 (Bkrtcy SDNY 2018), pp 47-48, citing Kannan (2017), p 43.

21 See Mevorach (2018a), pp 14-28.

22 See Bork (2018), p 32; Mevorach (2018a), p 25; Fletcher (2005), pp 209-210.

23 See generally, regarding the recognition of foreign discharge, Westbrook (2005).
} 
process. ${ }^{24}$ Ordinary private international law rules, such as consent, residency, presence in, or submission to, the foreign forum, which apply to commercial judgments generally, would not be determinative to the recognition and enforcement process when insolvency-related judgments/orders emanate from a main proceeding.

Such distinction between enforcement of ordinary commercial judgments and judgments related to collective insolvency proceedings (which as such should be subject to special rules) was acknowledged by the UK Court of Appeal in the case of Rubin v. Eurofinance ${ }^{25}$ :

Albeit that they have the indicia of judgments in personam, the judgments of the New York court made in the adversary proceedings, are none the less judgments in and for the purposes of the collective enforcement regime of the bankruptcy proceedings and as such are governed by the sui generis private international law rules relating to bankruptcy and are not subject to the ordinary private international law rules preventing enforcement of judgments because the defendants were not subject to the jurisdiction of the foreign court. This is a desirable development of the common law founded on the principles of modified universalism. It does not require the court to enforce anything that it could not do, mutatis mutandis, in a domestic context. ${ }^{26}$

Non-submission or consent by a creditor, namely the attempt to avoid taking part in the central process, is exactly the type of territorial strategy in cross-border insolvency which modified universalism aims to overcome. ${ }^{27}$ Once a central process is underway, it should encompass and have effect regarding all stakeholders. The Court of Appeal in Rubin v. Eurofinance followed this norm and found that there was no unfairness in applying a special rule where the defendants are aware of the insolvency proceedings:

I see no unfairness to the defendants in upholding the judgments of the New York court. The defendants were fully aware of the claims being brought against them. After taking advice they chose not to participate in the New York proceedings. They took their chance that it would be difficult to bring proceedings here, possibly because TCT as a trust is not amenable to winding up; possibly because the greater part of the transactions impugned in New York could not have been attacked here because the repugnant activity took place before 4 April 2006 when the Regulations came into effect. Whatever

\footnotetext{
24 See In re Foreign Econ. Indus. Bank Ltd. 'Vneshprombank' Ltd., No. 16-13534, and In re Larisa Markus, No. 19-10096 (Bankr SDNY 8 October 2019) where judge Martin Glenn observed regarding the public policy exception that ' $[\mathrm{t}]$ he key determination is whether the procedures used in the foreign court meet our fundamental standards of fairness' (2019 LEXIS 3202 33, citing In re ENNIA Caribe Holding N.V., 594 BR 631, 640 (Bankr SDNY 2018)).

25 Rubin and another v. Eurofinance SA [2010] EWCA Civ. 895.

26 Ibid., para. 61.

27 See also Aconley et al. (2019), p 122, noting that '[i]ssues of presence and submission can be incredibly complex, particularly when the rules surrounding such concepts are not consistent across different jurisdictions'.
} 
their reasons, they made an informed judgment. I have no sympathy for them when it transpires that they were wrong. ${ }^{28}$

But this approach was not followed by the Supreme Court in Rubin ${ }^{29}$ (and indeed by courts in certain other cases), exposing uncertainties regarding the enforcement regime under the $\mathrm{MLCBI}$.

\section{Enforcement of Judgments Under the Model Law on Cross-Border Insolvency}

Domestic systems of law across the globe have largely failed to develop comprehensive rules specifically for the private international law of insolvency and, in any event, what has been developed in each system has only increased conflicts. ${ }^{30}$ The international community, therefore, designed a separate instrument for cross-border insolvency in the late 1990s - the UNCITRAL Model Law on Cross-Border Insolvency (MLCBI). Regionally too, for example in Europe, alongside general private international law instruments, ${ }^{31}$ a specific cross-border insolvency regime appliesthe European Insolvency Regulation (EIR). ${ }^{32}$ Globally, the regime takes the form of a model law, namely a non-binding instrument which provides uniform provisions for adoption. So far, the MLCBI has been adopted by 49 States. ${ }^{33}$

The MLCBI does not say this in so many words, but it generally follows the modified universalist norm and indeed has in turn influenced its development. ${ }^{34}$ Thus, the MLCBI requires that courts and insolvency representatives cooperate to the maximum extent possible in the course of international insolvencies. ${ }^{35}$ Notably, it requires quick recognition of a central (main) proceeding opened in the debtor's home country. ${ }^{36}$ The MLCBI also provides a uniform jurisdictional basis for recognition, referring to the debtor's centre of main interests (COMI). ${ }^{37}$ If the debtor has an 'establishment' (a place of operations where the debtor carries out a non-transitory economic activity with human means and goods or services ${ }^{38}$ ), the proceedings

\footnotetext{
${ }^{28}$ Rubin and another v. Eurofinance SA [2010] EWCA Civ. 895, para. 64.

29 Rubin (n. 3 above).

${ }^{30}$ Fletcher (2005), p 7.

31 See Brussels Regulation (Regulation (EU) 1215/2012 of the European Parliament and of the Council of 12 December 2012 on jurisdiction and the recognition and enforcement of judgments in civil and commercial matters (recast) [2012] OJ L 351/1.

32 Regulation 2015/848 of the European Parliament and of the Council of 20 May 2015 on Insolvency Proceeding [2015] OJ L 141/19 (EIR) (repealing Council Regulation 1346/2000, of 29 May 2000 on Insolvency Proceedings [2000] OJ L 160/1).

33 See https://uncitral.un.org/en/texts/insolvency/modellaw/cross-border_insolvency/status.

34 Mevorach (2018a), pp 111-124.

35 MLCBI (n. 2 above), Arts. 25-27.

36 Ibid., Arts. 15-17.

37 Ibid., Art. 17.

38 Ibid., Art. 2.
} 
should be recognized as non-main proceedings. ${ }^{39}$ Local courts are given residual control as they decide whether to grant recognition, which is not automatic and must be sought. ${ }^{40}$ However, recognition should be granted as a matter of course based on objective criteria (the existence of foreign insolvency proceedings, main or nonmain) subject to a strict public policy safeguard. ${ }^{41}$ Certain relief (a stay) is automatic following the recognition of main proceedings, ${ }^{42}$ and other (broad range of) relief ${ }^{43}$ is discretionary in that it depends on what is sought and it requires finding that creditors are adequately protected. ${ }^{44}$ The MLCBI also allows the court to provide any assistance to a foreign representative as permitted by the domestic law. ${ }^{45}$

Relief may also be granted to non-main proceedings. ${ }^{46}$ Yet, the instrument's provisions primarily aim to support the main process-only the recognition of main proceedings results in immediate effects. Furthermore, when granting relief to nonmain proceedings, 'the court must be satisfied that the relief relates to assets [...] that should be administered in the foreign non-main proceeding or concerns information required in the proceeding, 47

The MLCBI is obscure, though, on the issue of the enforcement of judgments and orders. While it includes provisions on cooperation, assistance, and relief (and relief may include any appropriate relief ${ }^{48}$ ) none of the provisions of the MLCBI explicitly mention the enforcement of judgments. In Rubin, the UK Supreme Court reversed the decision of the Court of Appeal (noted in the previous section) and refused to enforce an insolvency-related judgment of a US Bankruptcy Court, which was the main insolvency forum. ${ }^{49}$ The US court judgment was in default of appearance in respect of fraudulent conveyances and transfers (an insolvency-related judgment). The UK court concluded that neither the MLCBI provisions on assistance, cooperation or relief, nor common law provide special rules on the enforcement of insolvency judgments. ${ }^{50}$ Therefore, the court applied the ordinary common law rule

\footnotetext{
39 Ibid., Art. 17.

40 Ibid., Art. 15.

41 Ibid., Art. 6.

42 Ibid., Art. 20.

43 Including the examination of witnesses or the entrustment of the administration or realization of all or part of the debtor's assets to the foreign representative (ibid., Art. 21).

44 Ibid., Art. 22.

45 Ibid., Art. 7.

46 Ibid., Art. 21 (discretionary relief which may be granted upon recognition of a foreign proceeding, main or non-main).

47 Ibid., Art. 21(3). The EIR is even more robust where it requires that only one main proceeding is opened at the debtor's COMI and that this proceeding is automatically recognized and given effect to in other Member States (EIR, n. 32 above, Arts. 3(1) and 19). 'Secondary' proceedings may be opened where the debtor possesses an establishment, but the primary powers are given to the main process (ibid., Arts. 3(2),(3) and 19). The effects of the secondary proceedings are restricted to the assets of the debtor situated in the territory (ibid., Art. 3(2)). There is also a mechanism to avoid secondary proceedings (ibid., Art. 36).

48 MLCBI (n. 2 above), Art. 21(1)(g).

49 Rubin (n. 3 above).

50 Ibid. Cf. Cambridge Gas Transport Corp v. Official Committee of Unsecured Creditors of Navigator Holdings Plc [2006] UKPC 26; [2007] 1 AC 508.
} 
according to which a judgment in personam cannot be enforced against persons who were not present in the foreign country or did not submit to the jurisdiction of the court entering the judgment. ${ }^{51}$

Other countries have taken a firmer universalist approach, interpreting the MLCBI more inclusively regarding the enforcement of judgments. Notably, courts in the US have considered that the MLCBI, specifically the discretionary relief provision in Article 21, does allow the recognition and enforcement of insolvency judgments. ${ }^{52}$ Rubin was not very well-received internationally, ${ }^{53}$ yet it had further repercussions in the UK. ${ }^{54}$ In subsequent cross-border insolvency cases, UK courts have interpreted modified universalism narrowly when required to defer to foreign judgments, including by applying the old rule in Gibbs (the 'Gibbs rule'). ${ }^{55}$

The Gibbs rule provides that English courts will not enforce a foreign insolvency judgment discharging or modifying the terms of English-law-governed debt. ${ }^{56}$ The rule impacts on both enforcement and choice of law. Thus, the UK court applies ordinary choice of law rules concerning contracts ('the proper law of the contract') in the context of insolvency proceedings, ${ }^{57}$ and denies enforcement of the discharge when a different law is applied. ${ }^{58}$ Contrary to modified universalism, the Gibbs rule precludes deference to the central court's insolvency laws and judgments save to the extent that the central court process modifies or discharges debts that the UK court, applying the Gibbs rule, would regard as properly governed by the law generally applicable in the central court. More recently, in OJSC, the UK court followed Gibbs (and Rubin) and refused to grant a permanent stay which in effect would enforce a foreign (Azerbaijani) restructuring plan. ${ }^{59}$ The Court of Appeal, upholding the decision of the High Court, noted the criticism of the Gibbs rule. It rejected 'the charge of parochialism' concerning the rule, ${ }^{60}$ given that the court in Gibbs accepts that 'questions of discharge of a contractual liability are governed by the proper law

\footnotetext{
51 These principles are known as the 'Dicey rule'.

52 See e.g., In re Metcalfe \& Mansfield Alternative Investments, 421 BR 685 (Bankr. SDNY 2010), where the US court agreed to enforce Canadian discharges even though they contravened US law. See also Ho (2017), p 167 (referring to In re Metcalfe and noting that: 'This case demonstrates that the Model Law is not against the enforcement of foreign judgments').

53 Moss noted that ' $[\mathrm{t}]$ he decision in Rubin was perceived internationally as a blow to [...] international co-operation via the recognition and enforcement of insolvency-related judgments' (Moss 2019, p 23).

54 See e.g., Singularis Holdings Ltd v. Pricewaterhouse Coopers [2014] UKPC 36, [2015] AC 1675; Fibria Celulose S/A v. Pan Ocean Co Ltd [2014] EWHC 2124 (Ch).

55 Antony Gibbs \& Sons v. La Société Industrielle et Commerciale des Métaux (1890) LR 25 QBD 399.

56 See also Re OJSC International Bank of Azerbaijan [2018] EWCA Civ. 2802, para. 28 ("As the judge went on to note at [46], there is an exception to the rule if the relevant creditor submits to the foreign insolvency proceeding. In that situation, the creditor is taken to have accepted that his contractual rights will be governed by the law of the foreign insolvency proceeding. But the application before the judge proceeded on the basis, as it does before us, that this exception is not engaged').

57 See also Westbrook (2019), p 3.

58 It seems that the rule encompasses a choice of forum rule as well whereby only an English court can discharge English law governed debts (ibid., p 12).

59 In re OJSC International Bank of Azerbaijan, Bakhshiyeva v. Sberbank of Russia et al [2018] EWHC 792 (Ch), [2018] Bus LR 1270, affd, [2018] EWCA Civ. 2802, [2019] 2 All ER 713.

60 Re OJSC International Bank of Azerbaijan [2018] EWCA Civ. 2802, para. 30.
} 
of the contract, whether or not that law is English law [...]'. However, it recognized that:

[...] the rule may be thought increasingly anachronistic [...] In particular, there may now be a strong case for saying that, in the absence of a stipulation to the contrary, contracting parties should generally be taken to envisage that, upon the supervening insolvency of one party, a single law closely associated with that party should govern the rights of its creditors, wherever in the world its assets happen to be situated, and regardless of the proper law of the contract $[\ldots]^{61}$

The court in OJSC held, however, that the MLCBI is limited to procedural aspects of cross-border insolvency and does not include rules on choice of law. Therefore, creditors' substantive rights cannot be overridden by invoking the relief provisions in the MLCBI. ${ }^{62}$ As noted above, this approach is not widely held, and both Rubin and Gibbs have been strongly critiqued. ${ }^{63}$

Yet, Rubin highlighted a weakness in the MLCBI's regime: it is prone to inconsistent application or no application at all in relation to the enforcement of judgments emanating from insolvency proceedings. Empirical studies have shown that the MLCBI has been applied quite consistently and 'universalistically, ${ }^{64}$ including regarding the use of the instrument's discretionary relief. ${ }^{65}$ The enforcement of judgments (and deference to foreign law), however, was a matter of concern and a 'notable problem'. ${ }^{66}$ Requests to enforce judgments and give effect to foreign orders, which could be appropriate in various circumstances and could save costs of opening multiple proceedings, were sometimes not sought. This was likely because of uncertainties regarding the availability of such relief in the jurisdiction. For example, in the Japanese case of Azabu Tatemono, ${ }^{67}$ the Japanese court recognized the foreign US Chapter 11 proceedings under the Japanese version of the MLCBI. If the Japanese court had also enforced the debt discharge granted by the US court, the foreign proceedings would have been given universal effect. Enforcement, however, was not pursued and instead concurrent local proceedings in Japan were opened to assess and adjudicate the local claims.

Courts have been somewhat unsure regarding the extent to which they can rely on the MLCBI provisions to give universal effect to foreign judgments. The UK Court

\footnotetext{
61 Ibid., para. 31. See also Global Distressed Alpha Fund 1 Ltd Partnership v. PT Bakrie [2011] EWHC 256 (Comm); [2011] 1 WLR 2038.

62 Ibid., para. 89.

63 See notably In re Agrokor d.d. et al. 591 BR 163 (Bkrtcy SDNY 2018), where the United States Bankruptcy Court for the Southern District of New York recognized and enforced a settlement agreement noting (at p 192) that the Gibbs rule 'remains the governing law in England despite its seeming incongruence with the principle of modified universalism espoused by the Model Law and a broad consensus of international insolvency practitioners and jurists'. See also in Re Pacific Andes Resources Development [2016] SGHC 210.

64 See generally, Mevorach (2011); Westbrook (2013).

65 Mevorach (2011), p 543.

66 Ibid., p 546.

67 Azabu Tatemono, Tokyo District Court, 3 February 2006.
} 
of Appeal decision in Rubin, for example, granted the enforcement relief (previously denied by the lower court $)^{68}$ under common law principles, expressing a concern in this respect regarding the ambiguity in the MLCBI:

What troubles me is that the specific forms of cooperation provided by Article 27 do not include enforcement. Indeed there is no mention anywhere of enforcement yet the guidance clearly had it in mind. On the other hand cooperation 'to the maximum extent possible' should surely include enforcement, especially since enforcement is available under the common law. I would prefer to express no concluded view about the point since it is unnecessary to my decision. ${ }^{69}$

Even when universalist relief was granted under the MLCBI, for example, by a US court in Condor ${ }^{70}$ this was achieved after litigation and appeals. ${ }^{71}$

\section{Enforcement Under the Model Law on Insolvency Judgments}

The MLCBI appeared to have a gap or at the least there was uncertainty regarding the scope of its relief provisions. It was also clear that general private international law instruments exclude the enforcement of insolvency judgments from their scope. ${ }^{72}$ The new instrument - the MLIJ-thus aimed to address this gap or uncertainty, to 'fix' Rubin (and other case law following the same approach), ${ }^{73}$ and prevent further defections. ${ }^{74}$

However, the background to the MLIJ project was more compound. As noted above, some countries considered the MLCBI as already addressing the enforcement of insolvency judgments. Pursuant to this approach, the MLCBI could continue to be used for this purpose. There was also a concern about asset recovery generally, ${ }^{75}$ and the limited reach of the MLCBI which has not been adopted by all or by the majority of countries. It was considered that perhaps a new separate instrument that did not fully follow the MLCBI framework could induce greater participation, especially by

\footnotetext{
${ }^{68}$ Rubin v. Eurofinance SA [2009] EWHC 2129 (Ch).

69 Rubin v. Eurofinance SA [2010] EWCA Civ. 895, para. 63.

70 In re Condor Insurance Limited, 601 F.3d 319, 2010 WL 961613 (5th Cir. 2010).

71 Ibid. (the appellate court reversed the decisions of the first and second instance courts).

72 MLIJ Guide to Enactment (n. 5 above), p 12.

73 Ibid., p 11, referring as well to the decision of the Supreme Court of Korea of 25 March 2010 (case No. 2009Ma1600). See also generally, Han (2015); Takahashi (2011).

74 The Guide to Enactment notes the concern that other countries may follow Rubin especially as the MLCBI stresses that it should be interpreted with due regard to its international origin, to promote uniformity in its application (MLIJ Guide to Enactment, n. 5 above, pp 11-12).

75 The problem of asset-tracing and recovery in different contexts has since been further considered at an UNCITRAL Colloquium and may be addressed more comprehensively by UNCITRAL in the future (see UNCITRAL, International Colloquium on Civil Asset Tracing and Recovery (6 December 2019), https:// uncitral.un.org/en/assettracing).
} 
the offshore jurisdictions that tend to host companies' registered offices but often not the actual head-offices or the business (i.e. the COMI). ${ }^{76}$

The MLIJ, therefore, avoids referring to main, non-main proceedings or COMI. Instead, it focuses on the insolvency-related judgment. It also often tracks general private international law instruments concerning judgment enforcement, in particular the Convention on the Recognition and Enforcement of Foreign Judgments in Civil and Commercial Matters developed by the Hague Conference on Private International Law, which excludes insolvency from its scope. ${ }^{77}$

\subsection{Scope and Definitions}

The MLIJ has a specific scope where it applies to "the recognition and enforcement of an insolvency-related judgment issued in a State that is different to the State in which recognition and enforcement is sought'. Thus, it addresses the cross-border enforcement of judgments related to insolvency. This includes an outbound aspect where the MLIJ authorizes relevant bodies in the enacting State to seek recognition and enforcement abroad, ${ }^{78}$ and inbound provisions on the recognition and enforcement of judgments further described below. ${ }^{79}$

The definitions section in the MLIJ is, therefore, brief. It includes two definitions largely borrowed from the MLCBI — of 'insolvency proceeding' and 'insolvency representative', ${ }^{80}$ and two new definitions of 'judgment' and 'insolvency related judgment'. The definition of judgment is rather obvious and includes any decision which may be issued by any authority provided it has the same effect as a court. ${ }^{81}$ But the MLIJ clarifies the meaning of 'an insolvency-related judgment'. This definition is quite wide and covers a range of judgments and orders. Any judgment which 'arises as a consequence of or that is materially associated with an insolvency proceeding, ${ }^{82}$ is covered, if it was 'issued on or after the commencement of that insolvency proceeding' (the judgment commencing an insolvency proceeding is excluded from the MLIJ scope). ${ }^{83}$ The law thus covers both judgments with general effect, and orders in insolvency-related litigation between individual parties (in personam judgments). The MLIJ Guide to Enactment provides a (non-exhaustive) list of examples of such judgments, which explicitly include the type of judgments in issue in

\footnotetext{
76 See Pottow (2019), p 486 (noting that "some states are resistant to the bifurcation of "main" and "nonmain" proceedings and hence loathe the concept of COMI, which serves as the doctrinal foundation of such bifurcation'). See also on the position of offshore jurisdiction, Mevorach (2018a), p 70 (fn. 109).

77 Convention of 2 July 2019 on the Recognition and Enforcement of Foreign Judgments in Civil or Commercial Matters (https://www.hcch.net/en/instruments/conventions/full-text/?cid=137), Art. 2(e).

78 MLIJ (n. 5 above), Art. 5.

79 See Sects. 4.2 et seq.

${ }^{80}$ MLIJ (n. 5 above), Art. 2(a) and (b), which are almost identical to MLCBI (n. 2 above), Art. 2(a) and

(d) (which refer though to 'foreign' proceeding and representative).

81 Excluding interim measures of protection (MLIJ, n. 5 above, Art. 2(c)).

82 Whether or not that insolvency proceeding has closed (ibid., Art. 2).

83 Ibid., Art. 2(d)(ii).
} 
cases such as Rubin, namely avoidance of detrimental transactions, ${ }^{84}$ and those with general effect in issue in cases following the Gibbs rule: 'a judgment (i) confirming or varying a plan of reorganisation or liquidation, (ii) granting a discharge of the debtor or of a debt, or (iii) approving a voluntary or out-of-court restructuring agreement'. ${ }^{85}$

\subsection{Procedure for Recognition and Enforcement of Judgments}

The MLIJ delineates the steps and process for the recognition and enforcement of insolvency judgments. ${ }^{86}$ An insolvency representative or another person entitled to seek recognition abroad can seek such recognition/enforcement of the judgment in the enacting State ${ }^{87}$ by presenting documents evidencing the existence of a judgment and the fact that it is enforceable and effective. ${ }^{88}$ Indeed, as is common under private international law instruments, ${ }^{89}$ it is a condition for recognition that the judgment has effect and is enforceable in the originating country. ${ }^{90}$ After seeking recognition and enforcement of a judgment and before a decision is made, provisional relief may be granted 'where relief is urgently needed to preserve the possibility of recognizing and enforcing an insolvency-related judgment'. ${ }^{91}$

The judgment shall then be recognized and enforced unless the grounds for refusing recognition apply. ${ }^{92}$ It shall be given the same effect it has in the originating country. Alternatively, it shall be given the same effect it would have had if it had been issued by a court in the recognizing country. ${ }^{93}$ Recognition/enforcement shall be granted to a severed part of a judgment where this is what is sought or where only this part is capable of being recognized and enforced. ${ }^{94}$ The MLIJ also clarifies that this procedure (and nothing in this law) prevents the court in the enacting State from providing any additional assistance. ${ }^{95}$

\footnotetext{
${ }^{84}$ MLIJ Guide to Enactment (n. 5 above), p 34.

85 Ibid.

86 See also Hawthorn and Young (2018), p 197.

87 From a competent court. Recognition may also arise by way of defence or as an incidental question before such a court (MLIJ, n. 5 above, Art. 13(d)).

88 Ibid., Art. 11.

89 See Art. 4(3) of the 2019 Hague Enforcement Convention (n. 4 above).

90 MLIJ (n. 5 above), Arts. 9 and 13(a). Recognition/enforcement may also be postponed or refused if the judgment is the subject of review in the originating State or if the time limit for seeking ordinary review in that State has not expired. In such cases, the court may make recognition or enforcement conditional on the provision of such security (ibid., Art. 10).

91 Ibid., Art. 12.

92 Ibid., Art. 13.

93 If the insolvency-related judgment provides for relief that is not available under the law of the receiving State, that relief shall, to the extent possible, be adapted to relief that is equivalent to, but does not exceed, its effects under the law of the originating State (ibid., Art. 15).

94 Ibid., Art. 16.

95 Ibid., Art. 6.
} 


\subsection{Grounds to Refuse Recognition/Enforcement}

The key feature of the MLIJ, and indeed the longest, is Article 14, which delineates the ground to refuse recognition and enforcement of insolvency-related judgments, complementing Article 7 as well on public policy.

\subsubsection{Public Policy, Due Process, and Fraud}

The MLIJ includes the usual public policy safeguard, where actions governed by the law can be refused on the basis that they would be 'manifestly contrary to public policy'. 96 The provision in the MLIJ adds that public policy includes 'the fundamental principles of procedural fairness'. 97

Article 14 provides additional grounds akin to public policy and procedural fairness, typical in private international law instruments on enforcement. ${ }^{98}$ Thus, recognition and enforcement may be refused in cases where a judgment was obtained by fraud $;{ }^{99}$ or where there was no due notification about the institution of the proceeding giving rise to the judgment, or the manner of the notification was incompatible with the rules of the enacting country concerning service of documents. ${ }^{100}$

\subsubsection{Conflict with Other Judgments}

Again, in accordance with private international law instruments on enforcement, ${ }^{101}$ recognition/enforcement may also be refused where the judgment is inconsistent with a judgment issued in the State in a dispute involving the same parties, or with an earlier judgment issued in another State or with a judgment in a dispute between the same parties on the same subject matter. ${ }^{102}$

\subsubsection{Lack of Jurisdictional Basis}

The MLIJ also allows the court in the enacting country to refuse to recognize/ enforce a judgment if the origin of the judgment is in a forum that did not exercise jurisdiction on a proper basis. Proper bases include (i) consent; ${ }^{103}$ (ii) submission; ${ }^{104}$ (iii) the exercise of jurisdiction 'on a basis on which a court in this State could have exercised jurisdiction'; ${ }^{105}$ and (iv) the exercise of jurisdiction on a basis that 'was not incompatible with the law of this State'. ${ }^{106}$

\footnotetext{
96 Ibid., Art. 7.

97 Ibid., Art. 7.

98 See the 2019 Hague Enforcement Convention (n. 4 above), Art. 7(1)(a) and (b).

99 MLIJ (n. 5 above), Art. 14(b).

100 Ibid., Art. 14(a).

101 See the 2019 Hague Enforcement Convention (n. 4 above), Art. 7(1)(e) and (f).

102 MLIJ (n. 5 above), Art. 14(c) and (d).

103 Ibid., Art. 14(g)(i).

104 Ibid., Art. 14(g)(ii).

105 Ibid., Art. 14 (g)(iii).

106 Ibid., Art. 14 (g)(iv).
} 
The first and second grounds—consent and submission—are typical jurisdiction bases for the purpose of recognition/enforcement under general private international law, ${ }^{107}$ and were the bases to refuse enforcement in Rubin. ${ }^{108}$ The third and fourth refer to what is recognized as a proper basis domestically, or at least is not incompatible with domestic law. The fourth requires further clarification. The MLIJ Guide to Enactment explains that this provision is similar to the third basis (exercise of jurisdiction on a basis on which a court in the enacting State could have exercised jurisdiction), but that it is broader. ${ }^{109}$ It is not limited to "jurisdictional grounds explicitly permitted under the law of the receiving State'. ${ }^{110}$ Rather, it applies 'to any additional jurisdictional grounds which, while not explicitly grounds upon which the receiving court could have exercised jurisdiction, are nevertheless not incompatible with the law of the receiving State'. ${ }^{11}$

\subsubsection{Adequate Protection}

Another refusal ground is based on lack of 'adequate protection'. ${ }^{112}$ Recognition/ enforcement may be refused if ' $[\mathrm{t}$ ]he interests of creditors and other interested persons, including the debtor, were not adequately protected in the proceeding in which the judgment was issued'. To avoid delay and litigation, and indeed to clarify the type of judgments for which consideration of the effect on the general body of creditors is required, the MLIJ limits this refusal ground to a specific type of judgment that ' $[\mathrm{m}]$ aterially affects the rights of creditors generally'. ${ }^{113}$ The provision refers as examples to judgments 'determining whether a plan of reorganization or liquidation should be confirmed, a discharge of the debtor or of debts should be granted or a voluntary or out-of-court restructuring agreement should be approved.'.14

\subsubsection{Interference or Mismatch with Recognized Proceedings}

Two additional refusal grounds make certain connections between the MLIJ and the MLCBI and its underlying framework of recognizing collective proceedings. Thus, Article 14(e) allows courts to refuse enforcement if that would interfere 'with the administration of the debtor's insolvency proceedings, including by conflicting with a stay or other order that could be recognized or enforced in this State'. Article 14(h) includes an 'optional' provision for MLCBI enacting States to refuse enforcement where the judgment originated in a country whose proceeding was or

\footnotetext{
${ }^{107}$ See the 2019 Hague Enforcement Convention (n. 4 above), Art. 5(1)(e) and (f).

108 See text to n. 51 above.

${ }^{109}$ MLIJ Guide to Enactment (n. 5 above), p 61.

${ }^{110}$ Ibid.

111 Ibid.

${ }^{112}$ MLIJ (n. 5 above), Art. 14(f).

${ }^{113}$ See MLIJ Guide to Enactment (n. 5 above), p 25.

${ }^{114}$ MLIJ (n. 5 above), Art. 14(f)(i).
} 
would not be recognized by the enacting country under its MLCBI, subject to certain exceptions. ${ }^{115}$

\subsection{Article X}

The final article in the MLIJ, which does not follow the previous articles' sequence and is thus entitled Article X, clarifies that the intended scope of the MLCBI was broad, and inclusive of enforcement of judgments:

Notwithstanding any prior interpretation to the contrary, the relief available under [insert a cross-reference to the legislation of this State enacting article 21 of the UNCITRAL Model Law on Cross-Border Insolvency] includes recognition and enforcement of judgments.

Article X thus admits that the MLCBI and MLIJ overlap.

\section{Overlaps and Inconsistencies}

The question is whether, notwithstanding overlaps, the MLIJ still strengthens the regime or whether the result is inconsistencies that can undermine the cross-border insolvency system. The answer is mixed. As is argued below, overall the MLIJ adds robustness regarding the availability of the enforcement relief and the manner to seek it, but it entails a risk of weakening the law where it is obscure in relation to jurisdiction.

\subsection{Clarity Regarding What and How to Enforce}

The MLIJ focuses on the enforcement of judgments. The MLCBI only refers to proceedings. The definitions of judgments and insolvency-related judgments in the MLIJ thus add to the regime. The addition is quite trivial though. It was already possible, if enforcing insolvency judgments under the MLCBI, to draw from the body of case law that evolved in the context of the EIR enforcement provisions concerning judgments deriving from and linked to insolvency proceedings. ${ }^{116}$ Indeed, the MLIJ attempts to prevent overlap where the definition of an insolvency-related judgment excludes the commencement of the proceeding from the judgments that

\footnotetext{
115 The receiving court may refuse to recognize/enforce the judgment unless the insolvency representative of a proceeding that is or could have been recognized under the MLCBI (as enacted in the State) participated in the proceeding in the originating State to the extent of engaging in the substantive merits of the cause of action to which that proceeding related, and the judgment relates solely to assets that were located in the originating State at the time the proceeding in the originating State commenced. See also MLIJ Guide to Enactment (n. 5 above), p 23.

116 See EIR (n. 32), Art 32(1); Gourdain v. Nadler, Case C-133/78, ECLI:EU:C:1979:49, [1979] 3 CMLR 180; Seagon v. Deko Marty Belgium NV, Case C-339/07, ECLI:EU:C:2009:83, [2009] BCC 347; [2009] 1 WLR 2168; Polymer Vision R\&D Ltd v. Van Dooren [2011] EWHC 2951.
} 
can be enforced (as this is clearly covered under the MLCBI). ${ }^{117}$ But otherwise, all other judgments and orders are included in both instruments. The MLCBI does not exclude judgments from its scope. Article X of the MLIJ clarifies that such exclusion was not intended. The focus on proceedings in the MLCBI derives from universalism's aim of supporting a collective, centralized process, including the tools employed and judgments granted during (mostly) the main proceeding.

The instruments, therefore, overlap in terms of scope. The MLIJ does not deviate here from the MLCBI and universalism-there is no inconsistency on this point. The clarifications, although non substantive, are welcome and may reduce litigation and delay. The provisions on the recognition and enforcement of judgments in the MLIJ add further clarifications regarding process and procedure. Under the MLCBI, to seek enforcement, the insolvency representative would need to invoke the relief provisions following recognition of (usually) main proceedings. The MLIJ specifies what the representative needs to provide in terms of evidence, and the usual requirement that such judgment be enforceable, as explained above. Again, this is not in itself material but adds clarity. However, when considered together with the clear requirement to enforce and in view of biases on decision making (discussed next), the additions become material and can strengthen universalism.

\subsection{The Default Is Enforcement}

Unlike the MLCBI, there is no discretion regarding the enforcement of judgments in the MLIJ. Where the procedural conditions are met, the judgment 'shall' be enforced. The approach here is different and to some extent is inconsistent with the MLCBI. The difference is not dramatic because whilst enforcement is required, it is also subject to a range of refusal grounds, which go beyond public policy and adequate protection - the applicable safeguards under the MLCBI. Furthermore, the discretion under the MLCBI is not open-ended. It is derived from the idea that an insolvency representative may seek all sorts of relief and that not all relief is adequate in any given circumstances. While a stay is automatic to give an immediate breathing space to the business in distress, other relief, including the enforcement of a judgment, may be given depending on what the representative is requesting. The relief also follows the procedure for seeking recognition, which is based on objective criteria (the existence of main or non-main proceedings). There are also specific criteria indicating when relief that was requested may be refused and this is where creditors and other stakeholders are not adequately protected. ${ }^{118}$

However, the fact that the default rule under MLIJ is enforcement and indeed that enforcement is the explicit focused relief under this regime, may promote universalist choices. Cognitive biases also likely impact decisions of countries and their implementing institutions. As analysed in detail elsewhere, ${ }^{119}$ biases include loss aversion (overweighting of losses of sovereignty, compared with gains of deference

\footnotetext{
117 MLIJ (n. 5 above), Art. 2(d)(ii).

118 See text to n. 44 above.

119 See Mevorach (2018a), Ch 2.
} 
and cooperation), a status quo bias (preference for the current state of affairs which may be territorialist and path dependent), the endowment effect (difficulty to depart from existing endowments such as control over local entities and assets) and short termism (tendency to be driven by short-term concerns). These biases influence choices generally but can also play a role in international law and specifically in cross-border insolvency. ${ }^{120}$ Vagueness in rules can exacerbate these biases and undermine compliance, because of the tendency to focus on information that is prominent and explicit. ${ }^{121}$ The rather imprecise legislative framing of the relief provisions in the MLCBI, especially concerning the enforcement of judgments, might have contributed to territorial choices of courts and the inconsistent application of the framework in different jurisdictions. ${ }^{122}$ Enforcement is not mentioned explicitly in the MLCBI and is only implied within the opening 'any appropriate relief' language, and the availability of 'any additional relief', in the discretionary relief rule. ${ }^{123}$ Being explicit and focused matters. Default rules can also affect compliance as studies show that people tend to follow what is presented as the default. Defaults tend to be perceived as representing the existing state or status quo and change usually involves a trade-off. Adherence to a default option may also be due to perceiving the default rule as representing the recommended, endorsed, option. ${ }^{124}$

Biases may be especially acute when gains from cooperation and universalism are less vivid compared with perceived losses. For example, courts that are asked to turn over assets to a main process abroad, to the frustration of local creditors, may observe a concrete loss today, while longer term benefits of reorganization, increased international trade, certainty, and so forth are more ambiguous and harder to quantify. ${ }^{125}$ The ability to impose the country's laws regarding local assets, locally incorporated companies and local constituencies may also be perceived as an existing entitlement (endowment) of sovereignty and vested rights. Thus, sovereign actors may be disinclined to defer to foreign laws and judgments. They may naturally prefer imposing the country's laws even where the interests of local stakeholders are not at stake. ${ }^{126}$

The decision of the UK Supreme Court in Rubin (and other judgments along such lines) reflects such tendencies to focus on local concerns. The court noted that the introduction of judge-made law extending the recognition and enforcement of foreign judgments would be only to the detriment of UK businesses without any corresponding benefit'. ${ }^{127}$ Even though modified universalism has greater expected utility, departure from existing entitlements may be perceived as a loss-in this case, to local businesses, or in other cases local assets may be perceived as endowmentsand be given greater weight compared to the long-term gains.

\footnotetext{
120 Ibid., pp 49-79.

${ }^{121}$ Ibid., p 164.

122 Ibid., p 224.

${ }^{123}$ MLCBI (n. 2 above), Art. 21(1) and 21(1)(g).

${ }^{124}$ See in more detail Mevorach (2018a), pp 64, 94-95.

125 Ibid., p 67.

${ }^{126}$ Ibid., pp 69-70. See also Walters (2019), pp 73-77.

${ }^{127}$ Rubin (n. 3 above), para. 130.
} 


\subsection{Overlapping Refusal Grounds}

The refusal grounds in the MLIJ are elaborated, but many of them actually overlap with the MLCBI. As we have seen, Article 14 of the MLIJ contains additional refusal grounds akin to public policy and procedural fairness. These are refusal grounds usual in the context of enforcement and indeed they track provisions in private international law instruments as noted above, but they are largely overlapping both with the MLCBI and with MLIJ's own public policy provision. The refusal grounds based on inconsistency with other judgments are also quite trivial.

Adequate protection is a safeguard in both instruments. The MLIJ narrows it, though, to judgments which materially affect the rights of creditors and other stakeholders, as noted above. The MLIJ Guide to Enactment notes the overlap where it says that '[a] requirement for protection of the interests of creditors and other interested persons, including the debtor, is included in both the Model Law and the MLCBI'. ${ }^{128}$ Yet, it suggests that the safeguards apply in 'different situations'. The MLCBI requires that the court considers if creditors are adequately protected when 'granting, modifying or terminating provisional or discretionary relief under the MLCBI'. ${ }^{129}$ The idea is that 'there should be a balance between relief that might be granted to the foreign representative and the interests of the persons that may be affected by that relief'. ${ }^{30}$ The equivalent safeguard under the MLIJ has a more limited scope where it applies as a refusal ground regarding specific types of judgments. The difference is subtle, and it is only a difference of scope and focus. But the clarification of the scope of the safeguard is helpful and can avoid litigation. Indeed, consideration of the interests of the general body of creditors should not be required, under any of the instruments, regarding in personam judgments.

The refusal grounds in the MLIJ that seek to support collective proceedings (allowing to refuse enforcement if that would interfere with collective insolvency proceedings or if the judgment originated in non-recognizable proceedings) are important, especially if we envisage that certain countries may only adopt the MLIJ. But as such they largely reflect the MLCBI, where recognition and relief are granted to main or non-main proceedings, and where courts are required to be more cautious when granting relief to non-main proceedings. ${ }^{131}$

\subsection{Divergence Regarding Jurisdiction}

However, there is one key difference between the MLCBI and the MLIJ that risks undermining the MLCBI regime and universalism, and that is the jurisdictional basis for recognition and relief/enforcement. As we have seen, the MLCBI, in line with modified universalism, is a framework to mainly support the main proceedings. If recognition is granted to the main proceeding, certain relief is automatic and additional

\footnotetext{
128 MLIJ Guide to Enactment (n. 5 above), p 25.

129 Ibid., referring to Art. 22 of the MLCBI.

130 Ibid., referring to the MLCBI Guide to Enactment.

131 MLCBI (n. 2 above), Art. 21(3).
} 
relief can be sought. It is not envisaged that relief be rejected based on lack of jurisdiction, as the jurisdictional ground is already dictated by and addressed in the recognition process. The bases to refuse relief are rather the public policy and adequate protection safeguards. Indeed, in Rubin the court did exactly the opposite and refused to grant relief because the party did not consent/submit to the foreign jurisdiction, even though the judgment emanated from a recognized main proceeding. ${ }^{132}$ The decision in Rubin was, therefore, rightly perceived by many as a defection from the cross-border insolvency framework. ${ }^{133}$ In declining to assist in any way, the UK Supreme Court rendered the decision to recognize the US main proceeding on jurisdictional grounds quite moot.

The MLIJ does not clearly reverse the Rubin approach by following an explicit framework of support to the main insolvency process. It provides a host of jurisdictional grounds as bases for refusing the recognition/enforcement of judgments. These include consent/submission, which, as noted, are recognized refusal grounds concerning jurisdiction under general private international law. They are not, however, the type of bases that ought to determine whether to enforce or refuse the enforcement of insolvency judgments emanating from a central process under modified universalism. For example, non-submission of a creditor to the jurisdiction where the company has its COMI and where main proceedings are taking place should not be a reason not to enforce an avoidance judgment of the main court against the creditor, indeed contrary to Rubin.

Other jurisdictional grounds in the MLIJ depend on domestic laws or what is not incompatible with the domestic law. The fact that the insolvency proceeding was the main proceeding is not explicitly listed as a proper, independent, jurisdictional basis. Still, reference to domestic laws or what is not incompatible with them could (indirectly) promote the recognition of main proceedings because COMI has become quite a recognized jurisdictional basis in insolvency under domestic laws. Therefore, it can be expected that judgments of courts in forums where main proceedings take place, based on COMI, will be recognized going forward in countries that enact the MLIJ. For example, in EU legal systems, COMI is a recognized jurisdictional basis because of the direct application of the EIR, where main proceedings may only be opened where the COMI is located. ${ }^{134} \mathrm{COMI}$ is also the basis for recognition of foreign main proceedings under the MLCBI which was enacted by 49 States.

Yet, the MLCBI has not been adopted by all countries and the MLIJ is provided as a standalone instrument-it does not require adoption of the MLCBI, and it does not explicitly endorse the COMI (and establishment) concepts. Still, courts may accept COMI as a proper jurisdictional basis, also where this is not incompatible with their countries' laws. Such an approach is not guaranteed, though, where there is no explicit agreement on COMI as a primary basis for the enforcement of insolvency judgments. Furthermore, in the MLCBI even where it is adopted, COMI is only a basis for recognition/relief. The MLCBI does not unify international

\footnotetext{
132 See text to n. 49 above.

133 See n. 53 above.

134 EIR (n. 32 above), Art. 3.
} 
jurisdiction rules nor does it unify a choice of law rule based on COMI. Notably, while the norm which centralizes the law and the forum is gradually emerging, COMI is not yet widely recognized as grounds for the application of the forum law to insolvency-related issues. As the UK High Court in OJSC observed:

Put another way, our common law does not yield to, adopt or enforce the law of a COMI elsewhere than here, and the law of the COMI cannot be enforced in this jurisdiction, unless and to the extent that by treaty and/or statute that law is absorbed into and becomes in effect part of British law. Such assistance as a British court can provide in accordance with the theory and objectives of modified universalism is restricted to what by its own common law it has jurisdiction to do, or by what under such an express treaty or statute it is empowered to do [...]. ${ }^{135}$

As noted above, the MLIJ Guide to Enactment explains that the jurisdiction bases are broad and not limited to those explicitly permitted under the domestic law. They also include what is not incompatible with the law of the receiving State. The Guide further explains that the purpose of the provision is:

to discourage courts from refusing recognition and enforcement of a judgment in cases in which the originating court's exercise of jurisdiction was not unreasonable, even if the precise basis of jurisdiction would not be available in the receiving State, provided that exercise was not incompatible with the central tenets of procedural fairness in the receiving State. ${ }^{136}$

A report by INSOL International explains that this provision aims to address the judgment in Rubin. In similar circumstances, and pursuant to the MLIJ:

[...] for a UK court to refuse recognition and enforcement of a US judgment, a party must demonstrate that although the US court found jurisdiction under US law to enter the judgment and provided adequate notice of the proceeding to the judgment-debtor, the US court's judgment violates the 'central tenants of procedural fairness' in the UK. ${ }^{137}$

The UK court also noted in Bakhshiyeva v. Sberbank of Russia, ${ }^{138}$ regarding the tension between the Gibbs rule and modified universalism, that 'the introduction of a new Model Law concerning the recognition and enforcement of insolvency related judgments as proposed by UNCITRAL may solve the problem if ever adopted'. ${ }^{139}$

Thus, Rubin might be fixed by these provisions, but that depends on future interpretations of the MLIJ, which is somewhat obscure on jurisdictional bases and is not

\footnotetext{
$\overline{135}$ Re OJSC International Bank of Azerbaijan, Bakhshiyeva v. Sberbank of Russia et al [2018] EWHC 792 (Ch), [2018] Bus LR 1270 (para. 86).

136 Ibid.

137 INSOL International (2019), p 9.

138 Re OJSC International Bank of Azerbaijan, Bakhshiyeva v. Sberbank of Russia et al [2018] EWHC 792 (Ch), [2018] Bus LR 1270.

139 Ibid., para. 160. See also Re OJSC International Bank of Azerbaijan [2018] EWCA Civ. 2802, para. 78.
} 
fully consistent with the general cross-border regime. ${ }^{140}$ The jurisdictional grounds in the MLIJ are broad and, especially a jurisdictional basis which is not incompatible with domestic law, would not require that the basis be identical to what is provided locally. Yet, there is a risk that courts might not see 'incompatible' as the same as fundamental fairness in the public policy/adequate protection sense (per the INSOL interpretation in the quote above) where these grounds are already covered in Articles 7, 14(a), 14(c) and 14(f)) of MLIJ. The fact that the MLIJ refrained from making any reference to the notion of main proceedings/COMI and linking its recognition/enforcement regime primarily to such proceedings, at the least creates ambiguities regarding support to a centralized process. Thus, countries that may enact the MLIJ as a stand-alone instrument (see further below on alternative ways of implementation) without becoming parties to the MLCBI or otherwise recognizing COMI as a jurisdiction basis for insolvency, ${ }^{141}$ may not enforce orders and judgments emanating from main proceedings if there is no submission or consent.

The MLIJ does reject the Rubin approach, though, in Article X, which states that the intention is to include the enforcement of judgments in the MLCBI relief provisions. ${ }^{142}$ This article, however, is quite disconnected from the rest of the MLIJ text technically and in substance. The relief in Article 21 of the MLCBI (to which Article X refers) is discretionary, whilst Article 13 of the MLIJ (the operational article on enforcement) requires that judgments shall be recognized and enforced if they meet the requirements. The MLIJ also includes definitions and procedural requirements that do not exist in the MLCBI. Importantly, Article X reflects an international agreement that relief, primarily to main proceedings, includes the enforcement of judgments. The main text of the MLIJ, however, does not clearly and explicitly follow the same approach. The MLIJ Guide to Enactment also confirms that Article X relates to the interpretation of the MLCBI, and therefore 'it is not intended that it be included in legislation enacting this Model Law'. ${ }^{143}$ As has been observed by the late Gabriel Moss, '[t]his is an odd suggested provision'. ${ }^{144}$ The peculiarity of Article X can be explained by the divergent views and controversy concerning the MLCBI relief provisions and their coverage of enforcement of judgments. Article X does clarify this and resolves that controversy, but in view of the development of the MLIJ alongside this clarification, there is also a potential for inconsistency.

\footnotetext{
${ }^{140}$ See also Pottow (2019), p 500 ('This language from the GTE [Guide to Enactment] is a thinly veiled (if veiled at all) rebuke of Rubin').

${ }^{141}$ Instead, they may, for example, rely solely on place of incorporation.

${ }^{142}$ See also MLIJ Guide to Enactment (n. 5 above), p 25.

143 Ibid., para. 127.

${ }^{144}$ Moss (2019), p 21.
} 


\section{Implementation}

The practical question is whether in view of overlaps and inconsistencies, countries should (or should not) adopt the MLIJ and if they should adopt it, in what way. The MLIJ is quite obscure concerning the manner of adoption. It is stated in the preamble that the MLIJ's purpose is '[w]here legislation based on the UNCITRAL Model Law on Cross-Border Insolvency has been enacted, to complement that legislation' ${ }^{145}$ This suggests that the MLIJ and MLCBI should be linked and complementary. Yet, enactment of the MLCBI is not stated as an aim or precondition. It is only 'where' the MLCBI was adopted that MLIJ would complement such legislation. It is also not clear if the MLIJ should complement the MLCBI by operating alongside it as a parallel system or if it should be interwoven within it. ${ }^{146}$ As shown above, the standalone nature of the instrument is not merely technical and the MLIJ is not easily aligned with the MLCBI. Divergences also reflect prior approaches, compromises, and mixed aims. It is, therefore, expected that consideration of adoption will instigate legislative discussions. Following implementation, questions may arise concerning the application and interpretation of the law. It is important that legislators and courts will have due regard in this process to the broad context of cross-border insolvency objectives, the existing instruments and additional developments.

\subsection{All Adopt!}

Countries that have considered that the MLCBI already allows courts to enforce judgments, might take the position that a new instrument on this matter is not needed for their cross-border insolvency system. Article X now clarifies that the enforcement of judgments is included in the MLCBI relief provisions. Therefore, it is arguably enough if countries adopt the MLCBI, or do nothing if they have enacted it already, because then according to Article X they can enforce insolvency-related judgments. $^{147}$

Such an approach would be misconceived. The effectiveness of international instruments for cross-border insolvency relies on their wide adoption. Enactment of the MLIJ by countries generally and especially by major economies with more experience with cross-border insolvency cases and the application of the MLCBI would send a signal about the importance of the regime, serving as a nudge and inducing participation by other countries, which would promote uniformity and consistency. ${ }^{148}$ In the process of adopting the MLCBI, which was finalized in 1997, the enactment of the regime in 2005-2006 by the USA and the UK gave it a boost and

\footnotetext{
145 MLIJ (n. 5 above), Preamble 1(f).

146 The MLIJ Guide to Enactment does provide some guidance on the relationship between and the complementary nature of the MLIJ and the MLCBI, noting areas of overlap, similarity, and discrepancy (MLIJ Guide to Enactment, n. 5 above, pp 23-25).

147 See also Hawthorn and Young (2018), p 197.

148 See on the effect of nudges in cross-border insolvency and the peer effect, Mevorach (2018a), pp 59, 65-66, 74-75, 77.
} 
seems to have induced other countries to follow. ${ }^{149}$ Once a good number of leading economies had adopted the MLCBI, there was also more leverage when international organizations such as the World Bank made efforts to introduce the MLCBI into legal systems, especially in developing countries. ${ }^{150}$

Importantly, the MLCBI is currently vague regarding the enforcement of judgments. The MLCBI speaks of proceedings rather than judgments, and in its relief provisions the enforcement of judgments is not specified explicitly. As a result, the MLCBI does not include concrete definitions and procedures for the seeking of recognition and the enforcement of insolvency judgments. It also does not cover nonCOMI/establishment judgments. Article X does not fill these gaps. It only clarifies that the relief available under the MLCBI includes recognition and the enforcement of judgments notwithstanding prior interpretation. It does not provide the detailed procedure for seeking enforcement. Additionally, the enforcement regime under the MLIJ is stronger where enforcement is required (subject to refusal grounds), compared with the MLCBI where enforcement is a matter of discretionary relief.

Where the MLIJ is enacted, foreign users would have a clearer guidance on seeking enforcement of judgments. Implementing institutions in the country could also then follow a stronger, more straight-forward procedure when enforcing insolvencyrelated judgments, avoiding conflicting judgments and interpretations within the jurisdiction, saving litigation costs. Even in countries such as the United States, which has been generous when applying the MLCBI, decisions regarding recognition, enforcement and effect to foreign orders and judgments have not always been consistent. ${ }^{151}$ Furthermore, often generosity has at least partially relied on comity (which indeed is embedded in the MLCBI as it is enacted in the United States). ${ }^{152}$ But comity is a precarious and unreliable basis for the recognition and enforcement of judgments. 153

\footnotetext{
${ }^{149}$ In the decade between 2005-2015, more than thirty additional countries enacted legislation based on the MLCBI.

${ }^{150}$ Mevorach (2018a), p 75.

151 See e.g., In re Elpida Memory Inc, No 12-10947 (D Del 16 Nov. 2012) where the court when asked to recognize an asset sale transaction which was already approved by a foreign main reorganization proceedings instead applied the domestic rules concerning assets sales, and in re Qimonda (2013) 737 F3d 14 where the court refused to defer to German law which permitted the cancellation of US patent licences, even though the German bankruptcy system was considered in line with fundamental fairness standards. Cf. In re Avanti Communications Group plc, 582 BR 603, 614 (Bankr. SDNY 2018) and In re Energy Coal SPA (2018) 582 BR 619 where the court gave effect to foreign restructurings.

${ }^{152}$ See e.g., In re Daebo International Shipping Co, Ltd, 543 BR 47 (2015); In re Atlas Shipping A/S, 404 BR 726, 739 (Bankr. SDNY 2009). These decisions were primarily based on the MLCBI as enacted in the USA, but reaching universalist decisions required reference to comity, enshrined in the US version of the MLCBI. The court in re Daebo, referring as well to re Atlas noted that: 'Chapter 15 "contemplates that the court should be guided by principles of comity and cooperation with foreign courts in deciding whether to grant the foreign representative additional post recognition relief" (In re Daebo International Shipping Co, Ltd, 543 BR 47 (2015), para. 2).

${ }^{153}$ See also Chung (2014), pp 96, 104 (noting that comity is ambiguous and ill-defined); Beckering (2008), p 281 (noting that: 'The major historical impediment to achieving sustainable unification in cross-border corporate insolvency administration is comity based theoretical analysis in bankruptcy reorganization for dissolution cases' and that: 'By maintaining comity as the focal point in the [...] United States judiciary, which is still possible under the construct of Chapter 15, forward-looking reform of antiquated bankruptcy law in foreign countries will be negligible, at best').
} 


\subsection{Avoiding Carve-Outs}

Certainly, the MLIJ should be welcomed by countries that 'called for it', such as the United Kingdom, Japan and South Korea, whose courts have interpreted the MLCBI narrowly. UK courts explicitly sought clear legislation through international negotiations to be able to enforce judgments on bases beyond the general ones under their domestic laws. ${ }^{154}$ The UK Supreme Court in Rubin, refusing to enforce the New York judgment based on common law or the provisions in the MLCBI, noted that typically rules on enforcement are a product of negotiations, and that in any event it is an area where a change in the law requires legislation:

In my judgment, the dicta in Cambridge Gas and HIH do not justify the result which the Court of Appeal reached. This would not be an incremental development of existing principles, but a radical departure from substantially settled law. There is a reason for the limited scope of the Dicey Rule and that is that there is no expectation of reciprocity on the part of foreign countries. Typically today the introduction of new rules for enforcement of judgments depends on a degree of reciprocity. The EC Insolvency Regulation and the Model Law were the product of lengthy negotiation and consultation.

A change in the settled law of the recognition and enforcement of judgments, and in particular the formulation of a rule for the identification of those courts which are to be regarded as courts of competent jurisdiction (such as the country where the insolvent entity has its centre of interests and the country with which the judgment debtor has a sufficient or substantial connection), has all the hallmarks of legislation $[\ldots]^{155}$

Adoption of the MLIJ by countries that have interpreted the MLCBI restrictively can resolve the persisting uncertainty in these systems concerning enforcement of judgments and orders. In the UK, for example, the Supreme Court may, if faced again with circumstances akin to Rubin or Gibbs, change direction having regard to the international agreement in the MLIJ, even prior to enactment of the instrument. Yet, enactment of the model law can provide the statutory basis for consistent recognition and enforcement of judgments.

There is a risk though that countries that have interpreted the MLCBI narrowly will end up applying the MLIJ restrictively as well, or even explicitly carveout certain types of judgments or scenarios in which the local court may not be obliged to recognize and enforce a foreign judgment. For example, legislators could seek to exempt the enforcement of a foreign discharge where the debt was governed by the local law (following a Gibbs-like rule). ${ }^{156}$ The 'trick' is to see the MLIJ and its implementation process as an exercise of international development rather than as a

\footnotetext{
154 See also Lord Neuberger (2017), para. 26 (pointing to national inconsistencies that require 'more international legislative action').

155 Rubin (n. 3 above), paras. 128-129.

156 See Clarke (2019).
} 
process of aligning and modifying instruments to fit with pre-existing domestic rules and practices.

\subsection{Alterative I: Adoption of the Model Law on Judgments as a Stand-Alone Instrument}

The MLIJ may be adopted almost verbatim with limited modifications as a separate instrument like it is designed. The advantage of this approach is that it will ensure uniformity and alignment with the original international instrument, and at least in terms of enactment, it will demonstrate full compliance with the international law. Arguably, promoting the MLIJ as an instrument separate from the MLCBI would also persuade more countries to adopt it, including countries that have been resistant to COMI-the basis for recognition of main proceedings under the MLCBI. Encouraging wide adoption is in line with modified universalism, which requires a broad practice of the norm as it relies on uniformity of the private international law aspects of insolvency. Indeed, the norm can become customary international law if it is followed consistently by countries based on a belief in the conformity of the practice with international law. ${ }^{157}$

If adoption is by a country that already adopted the MLCBI or that is intending to adopt it, then, implementation may also include an amendment pursuant to Article $\mathrm{X}$ of the MLIJ. Depending on prior interpretations of Article 21 of the MLCBI in the country, the equivalent of Article 21 may be clarified to say that any other relief includes the enforcement of judgments as well. The result is that there will be two laws pursuant to which enforcement of insolvency judgments can be sought.

In a future case, if enforcement is sought concerning a judgment or order granted by a court in a main proceeding, it may be simplest to invoke the MLCBI. A representative may seek recognition of the proceeding anyway, and following this ask for various relief, which may include the enforcement of orders/judgments. The representative should foresee that enforcement will be granted if there are no anticipated concerns regarding public policy/adequate protection. The MLIJ procedural requirements can further provide guidance regarding the need for such a judgment to be enforceable and not inconsistent with another. If enforcement is requested concerning a judgment emanating from another forum, then it may be sought under the MLCBI (if from non-main proceedings) or the MLIJ, but there will be hurdles to overcome including showing that such enforcement will not interrupt the main proceeding.

If a representative invokes the MLIJ where the judgment/order was granted by a main forum, because she so chooses or because the MLCBI is not available in the foreign country, then as a matter of principle, enforcement should be granted (if there are no problems concerning public policy/adequate protection). The jurisdiction bases within the refusal grounds in the MLIJ should be applied in line with the clarifications in the MLIJ Guide to Enactment and modified universalism

157 See generally, Mevorach (2018b). 
(increasingly becoming an international norm) to view COMI as an acceptable jurisdictional ground.

Indeed, if countries adopt the MLIJ driven by a reluctance to join the MLCBI, they may also be reluctant to interpret the MLIJ broadly in this way. Article X may also have no effect as it will not be enacted or be of assistance in the interpretation of the MLCBI (as this instrument will not be available in the domestic system). Thus, while the standalone document might encourage buy-in, the trade-off is an inconsistency problem. At the same time, it is frankly difficult to see why countries will find the MLIJ attractive only for the purpose of allowing representatives from other countries to enforce and recover assets in their jurisdictions, without participating more generally in the uniform cross-border border insolvency system which supports collective proceedings.

\subsection{Alternative II: Integration of the Model Law on Judgments in the Cross-Border Insolvency Framework}

A more arduous task for legislators, but one which can ultimately promote a coherent system, would be to merge the MLIJ and the MLCBI into one instrument, whether the MLCBI is already law in the country or will be enacted at the time of enactment of the MLIJ. Especially if done in consultation with UNCITRAL, uniformity can be promoted and supported. An integrated approach promoted worldwide can also encourage more countries to adopt the MLCBI when they consider adoption of the MLIJ, thus advancing the cross-border insolvency system generally. ${ }^{158}$ It can also reassure countries that already adhere to a regime where recognition and relief is primarily to main proceedings, such as EU Member States, that the MLIJ will not deviate from that framework, urging more such countries to adopt the existing and new UNCITRAL model laws. ${ }^{159}$

Whilst it is possible just to slightly amend Article 21 of the MLCBI (to which the MLIJ refers in Article X) and note that additional discretionary relief that may be granted includes enforcement of judgments, a fuller amalgamation of the regimes could strengthen the framework. The MLIJ definitions where they do not already overlap with those in the MLCBI-importantly, the definition of insolvencyrelated judgments - could be added as an elaboration of the definitions provided in the MLCBI (Article 2). The relief section in the MLCBI (Articles 19-21) ${ }^{160}$ as enacted in the country could be clarified to explicitly refer to the recognition and enforcement of insolvency-related judgments. In this context, the law could provide the detail of the procedure and conditions for the recognition and enforcement

\footnotetext{
158 There is some indication of support to such approach in the INSOL Report which notes that '[n]early $70 \%$ of the INSOL survey respondents support the incorporation of the [MLIJ] Model Law into existing cross-border insolvency regimes' (INSOL International 2019, p 10).

159 See also McCormack and Anderson (2017), p 553 (noting that adoption of the MLCBI either by the EU or unilaterally by Member States, which have not already adopted it, would be 'a welcome development' and that the EU and Member States should be assured by the fact that mandatory relief is only required regarding main proceeding under the MLCBI).

160 Relief in both the MLCBI and the MLIJ also includes provisional relief.
} 
of judgments as specified in the MLIJ. It could also simultaneously solidify the MLCBI as enacted (or when enacting it) by requiring, rather than just allowing, that following recognition as main proceeding, foreign judgments from this proceeding be recognized and enforced. In other words, Article X may not be enacted verbatim but inspire a more robust change in the law based on the main text of the MLIJ. It should also be clarified, in any event, that the judgment shall be given the same effect it has in the originating country or the same effect it would have had if it had been issued by a court in the recognizing country.

The MLIJ grounds to refuse recognition and enforcement akin to public policy (fraud, lack of notice, etc.) may be added and specified, or could be consumed by the general public policy safeguard already provided in Article 6 of the MLCBI. In any event, the consequences in practice are unlikely to be material. The adequate protection safeguard (Article 22 of the MLCBI) can be construed narrowly regarding the enforcement of judgments, to apply only to judgments which materially affect the rights of creditors generally, in line with the MLIJ. It should also be clarified that judgments would be enforced only where they are not inconsistent with other judgments as provided in the MLIJ and when they are enforceable in the original jurisdiction.

The additional grounds in Article 14(g) of the MLIJ that speak of consent/submission or other referrals to domestic laws may not be required when the insolvency proceeding is recognized as the main proceeding under the MLCBI. Proceedings recognized as foreign main proceedings would ideally receive the most support, including concerning orders and judgments, subject to public policy and adequate protection and unless there is inconsistency with another judgment. A distinction could be made explicitly in the law to clarify that recognition of the underlying proceedings as main proceedings suffices as a basis for recognition/enforcement of the judgments emanating from that jurisdiction (in line with Article X). No further analysis of 'compatibility' with domestic law may be required in such circumstances. In any event, application of the law and the enforcement process including the grounds to refuse enforcement in this way could fix Rubin and the rule in Gibbs.

Relief is also available to non-main proceedings (where the debtor has an establishment) under the MLCBI's discretionary relief provision. However, as noted earlier, the MLCBI states that before granting relief to such proceedings, the court should be satisfied that the relief relates to assets that should be administered in the foreign non-main proceeding or concerns information required in that proceeding. ${ }^{161}$ If the distinction between forms of proceedings is kept, a similar restriction should apply to the enforcement of judgments emanating from non-main proceedings.

Separate provisions can be added regarding the recognition/enforcement of insolvency-related judgments, which do not emanate from main or non-main proceedings. In any event, regarding such judgments that do not emanate from proceedings recognized under the MLCBI, the full range of rejection grounds should apply, including where enforcement might interfere with the administration of the debtor's insolvency process or because the foreign court did not have jurisdiction under

161 See text to n. 47 above. 
recognized general private international law (submission, consent, etc.). Support might be restricted concerning such foreign judgments in view of existing or forthcoming main proceedings or because there is no jurisdictional basis under the special cross-border insolvency system for enforcing such judgments. Judgments may be enforced, however, in the circumstances specified in Article 14(h) of the MLIJ, namely when the insolvency representative of a recognized proceeding participated and engaged in the proceeding concerning the foreign judgment which relates solely to assets that were located in the originating State at the time of the proceeding. ${ }^{162}$

\subsection{The Model Law on Judgments, and Groups}

The MLCBI does not provide specific rules for groups - a gap that was addressed in 2019 as UNCITRAL introduced a new model law on enterprise group insolvency (MLEGI). ${ }^{163}$ This model law complements the MLCBI and provides specific mechanisms to achieve group solutions. The MLEGI tracks the MLCBI's concepts of cooperation, coordination, recognition, relief, main and non-main proceedings and extends them to groups. ${ }^{164}$ It also adds new features unique to groups, importantly the concepts of 'group insolvency solution' which may be developed in a 'planning proceeding' thus supporting a concentrated process for the group as a whole (or a relevant part). ${ }^{165}$ The MLEGI provides mechanisms for deferring to that central group process, avoiding opening local proceedings, ${ }^{166}$ and providing a range of relief to support that process.

Thus, MLEGI is an important addition to the global framework for international insolvency. When enacting MLIJ, consideration should be given to enacting MLEGI as well (or vice versa) and to ensuring consistency between the instruments. The interaction of MLEGI and MLIJ has not been considered and there is no equivalent of Article $\mathrm{X}$ to tell us how to read MLEGI in that regard. The MLEGI does work well as a separate instrument as it is in line and is fully consistent with the MLCBI, or it could be quite easily merged with the MLCBI. Importantly, the regime would be improved and become coherent if in the process it is clarified (in the law or in practice when the law is applied) that relief under the MLEGI includes the enforcement of judgments and orders of the planning process, subject to public policy and adequate protection of the interests of creditors of each enterprise group member. ${ }^{167}$

\footnotetext{
162 MLIJ (n. 5 above), Art. 14(h)(ii).

163 UNCITRAL Model Law on Enterprise Groups Insolvency (2019) (advanced copy), https://uncitral. un.org/sites/uncitral.un.org/files/media-documents/uncitral/en/mlegi_-_advance_pre-published_version_e.pdf.

164 Ibid., Chapter 2.

165 Ibid., Art. 2.

166 Ibid., Arts. 30-32.

167 Art. 27 of the MLEGI (n. 163 above) provides that '[i]n granting, denying, modifying or terminating relief under this Law, the court must be satisfied that the interests of the creditors of each enterprise group member subject to or participating in a planning proceeding and other interested persons, including the enterprise group member subject to the relief to be granted, are adequately protected'.
} 


\subsection{Uniform Choice of Law Rules}

With the adoption of the MLIJ and the MLEGI in 2018-2019, the cross-border insolvency system has become more complete (assuming the instruments will be enacted by a significant number of countries) but it is still missing an important piece-uniform rules on choice of law. The absence of choice of law rules can also impact the implementation and application of MLIJ. It was noted above how choice of (insolvency) law is intricately linked to the enforcement of (insolvency) judgments (see the discussion above of the Gibbs rule ${ }^{168}$ ). When a local court is required to enforce a judgment or an order of a foreign court, it may indirectly also need to defer to the foreign law. If enforcement is based on cross-border insolvency-specific grounds like the fact that the foreign proceeding is the main proceeding, rather than the general domestic private international law rules, deference may not be readily accepted. Indeed, in Rubin, the court did not consider the issue of choice of law. It refused to enforce the avoidance judgment in the absence of submission or consent. It can be presumed that if the foreign court had exercised jurisdiction based on ordinary (English) private international law, the English court would have enforced the judgment. ${ }^{169}$ It could also be the case that the judgment would have been enforced if the foreign court had applied English (avoidance) law.

To compare, in the EU, the position on enforcement is clear as judgments emanating from the automatically recognized proceedings opened in a Member State must be enforced, and there are no additional refusal grounds beyond the public policy safeguard. ${ }^{170}$ But the EIR provides uniform rules concerning choice of law. Under this regime, the law of the main forum (lex fori concursus) applies, ${ }^{171}$ subject to a set of exceptions (and the possibility that secondary proceedings are opened). ${ }^{172}$

The MLCBI does not prohibit deference to the forum laws but does not explicitly provide which law applies in main or secondary proceedings. The original drafters of the MLCBI proceeded with caution when they, for the first time, designed an international framework for cross-border insolvency in 1997. They seemingly preferred to leave out an explicit relief concerning the application of foreign law, ${ }^{173}$ allowing the practice to develop through the application of the MLCBI flexible provisions. ${ }^{174}$ But we have seen the consequences of vagueness in the cross-border insolvency instrument. Thus, while the enforcement of judgments in line with universalism is achievable, especially if the MLIJ is taken on board in the manner

\footnotetext{
168 See text to nn. 56-58 above.

169 See Rubin and another v. Eurofinance SA and others and New Cap Reinsurance Corporation (in Liquidation) and another v. AE Grant and others [2012] UKSC 46 where regarding New Cap, the court found that because the appellant had in fact submitted to the Australian Court's jurisdiction, the normal common law test for enforcement was satisfied.

170 EIR (n. 32 above), Art. 32.

171 Ibid., Art. 7.

172 Ibid., Arts. 8-18.

173 See generally, Gropper (2014).

174 See generally, Gopalan and Guihot (2015) (arguing that the MLCBI was intentionally vague in various areas).
} 
suggested above, it requires completion of the framework by implementing uniform, globally accepted rules on choice of law. ${ }^{175}$

\section{Conclusion}

The international community has clearly signalled its dissatisfaction about defections from modified universalism where the MLCBI regime was interpreted narrowly regarding the enforcement of insolvency judgments. It was also concerned about gaps in private international law instruments, which exclude insolvency from their scope, including regarding the enforcement of judgments. The process of closing the gap by UNCITRAL through the development of the MLIJ has been arduous, however, in view of divergences of interpretation of the existing framework (in particular the MLCBI) and what is, in this light, the aim of the new instrument.

This article highlighted overlaps between the cross-border insolvency instruments and the risks of inconsistencies, which should inform the implementation process by countries as well as future application of the law following its adoption in legal systems. It was shown that the MLIJ does add vigour to the cross-border insolvency system where the requirement to enforce and manner for seeking enforcement of insolvency judgments is explicit and clear. The MLIJ should, therefore, be adopted widely. At the same time, ambiguities in this instrument concerning refusal grounds based on proper jurisdiction and inconsistencies with the MLCBI could undermine the system. Against this backdrop, the article considered different ways of implementing the MLIJ and using it in future cases, with a view of maximizing its potential, including in view of further developments concerning enterprise groups and choice of law.

Apart from addressing an important weakness in the existing cross-border insolvency regime where the conditions for enforcing insolvency judgments have not been clear, the MLIJ serves as a prompt to countries to consider if their cross-border insolvency laws need improvement. In particular, as UNCITRAL notes in its decision to adopt the MLIJ, countries should '[...] continue to consider implementation of the UNCITRAL Model Law on Cross-Border Insolvency (1997)'. ${ }^{176}$ Such wide adoption of the MLCBI as well as the newer additions can increase preparedness for future international insolvencies.

Acknowledgements The author would like to thank Adrian Walters and Allan Gropper for helpful comments, and to the participants at the Insolvency Lawyers' Association (ILA) Academic Forum, Allen

\footnotetext{
175 The choice of law problem has been considered a 'candidate' for possible future work since 2013 (United Nations Commission on International Trade Law, A/CN.9/798, Report of Working Group V (Insolvency Law) on the work of its forty-fourth session (Vienna, 16-20 December 2013), para. 30, https ://undocs.org/en/A/CN.9/798). It may be due for further deliberations by UNCITRAL Working Group $\mathrm{V}$ following the UNCITRAL/HCCH Virtual Colloquium on Applicable Law in Insolvency Proceedings, which took place on 11 December 2020 (https://uncitral.un.org/en/applicablelawcolloquium).

176 Report of the United Nations Commission on International Trade Law Fifty-first session (25 June-13 July 2018, https://undocs.org/en/A/73/17\%20, p 21).
} 
\& Overy, 29 March 2019 where preliminary ideas concerning this article were presented. All mistakes made are solely the author's.

Open Access This article is licensed under a Creative Commons Attribution 4.0 International License, which permits use, sharing, adaptation, distribution and reproduction in any medium or format, as long as you give appropriate credit to the original author(s) and the source, provide a link to the Creative Commons licence, and indicate if changes were made. The images or other third party material in this article are included in the article's Creative Commons licence, unless indicated otherwise in a credit line to the material. If material is not included in the article's Creative Commons licence and your intended use is not permitted by statutory regulation or exceeds the permitted use, you will need to obtain permission directly from the copyright holder. To view a copy of this licence, visit http://creativecommons.org/licen ses/by/4.0/.

\section{References}

Aconley L, Marshall J, Allen \& Overy (2019) What impact might a no-deal Brexit have on cross-border insolvencies and restructurings. https://www.allenovery.com/en-gb/global/news-and-insights/ publications/what-impact-might-a-no-deal-brexit-have-on-cross-border-insolvencies-and-restr ucturings. Accessed 12 Jan 2021

Beckering KJ (2008) United States cross-border corporate insolvency: the impact of Chapter 15 on comity and the new legal environment. Law Bus Rev Am 14:281-312

Bork R (2018) Principles of cross-border insolvency law. Intersentia, Cambridge

Chung JJ (2014) In re Qimonda AG: the conflict between comity and the public policy exception in Chapter 15 of the Bankruptcy Code. Boston Univ Int Law J 32:91-121

Clarke S (2019) The new model law: goodbye to Gibbs. https://hardwicke.co.uk/the-new-model-lawgoodbye-to-gibbs/. Accessed 23 Oct 2020

Fletcher IF (2005) Insolvency in private international law. Oxford University Press, Oxford

Gopalan S, Guihot M (2015) Recognition and enforcement in cross-border insolvency law: a proposal for judicial gap-filling. Vanderbilt J Transnatl Law 48:1225-1284

Gropper AL (2014) The curious disappearance of choice of law as an issue in Chapter 15 cases. Brook J Corp Financ Commer Law 9(1):151-179

Han M (2015) Recognition of insolvency effects of a foreign insolvency proceeding: focusing on the effect of discharge. In: Ramaswamay MP, Ribeiro J (eds) Trade development through harmonization of commercial law. New Zealand Association for Comparative Law, Wellington, pp 345-364

Hawthorn D, Young M (2018) Remodelling the model law: the model law on recognition and enforcement of insolvency-related judgments. Corp Rescue Insolv 195-197

Ho LC (2017) Cross-border insolvency, a commentary on the UNCITRAL Model Law. Global Law and Business, 4th edn. Globe Law and Business, London

INSOL International (2019) UNCITRAL's model law on recognition and enforcement of insolvencyrelated judgments-a universalist approach to cross-border insolvency. March 2019. https:// www.blankrome.com/sites/default/files/2019-03/uncitralmodellaw-antonoffzucker2019.pdf. Accessed 21 Jan 2021

Kannan R (2017) The Gibbs principle: a tether on the feet of good forum shopping. Singap Acad Law J 29:43-74

LoPucki LM (1999) Cooperation in international bankruptcy: a post-universalist approach. Cornell Law Rev 84:696-762

LoPucki LM (2000) The case for cooperative territoriality in international bankruptcy. Mich Law Rev 98:2216-2251

McCormack G, Anderson H (2017) Brexit and its implication for restructuring and corporate insolvency in the UK. J Bus Law 7:533-556

Mevorach I (2011) On the road to universalism: a comparative and empirical study of UNCITRAL Model Law on Cross-Border Insolvency. EBOR 12:517-557

Mevorach I (2018a) The future of cross-border insolvency: overcoming biases and closing gaps. Oxford University Press, Oxford 
Mevorach I (2018b) Modified universalism as customary international law. Texas Law Rev 96:1403-1436

Mevorach I, Walters A (2020) The characterization of pre-insolvency proceeding in private international law. EBOR. https://doi.org/10.1007/s40804-020-00176-X

Moss G (2019) UNCITRAL model law on recognition and enforcement of insolvency-related judgments. Insolv Int 32:21-24

Neuberger D (2017) Keynote speech at the international insolvency institute annual conference: the Supreme Court, the Privy Council and international insolvency. https:/www.supremecourt.uk/docs/ speech-170619.pdf. Accessed 23 Oct 2020

Paul JR (1991) Comity in international law. Harv Int Law J 32:1-19

Pottow JAE (2019) The dialogic aspect of soft law in international insolvency: discord, digression, and development. Mich J Int Law 40(3):479-503

Takahashi S (2011) The reality of the Japanese legal system for cross-border insolvency driven by fear of universalism. https://www.iiiglobal.org/sites/default/files/media/2011Prizepaper.pdf. Accessed 12 June 2020

Walters A (2019) Modified universalisms \& the role of local legal culture in the making of cross-border insolvency law. Am Bankruptcy Law J 93:4-110

Westbrook JL (1991) Choice of avoidance law in global insolvencies. Brooklyn J Int Law 17:499-538

Westbrook JL (2000) A global solution to multinational default. Mich Law Rev 98:2276-2328

Westbrook JL (2005) Chapter 15 and discharge. Am Bankruptcy Inst Law Rev 13:503-520

Westbrook JL (2013) An empirical study of the implementation in the United States of the Model Law on Cross Border Insolvency. Am Bankruptcy Law J 87(2):247-270

Westbrook JL (2019) Comity and choice of law in global insolvency. Texas Int Law J 54(2):1-14

Publisher's Note Springer Nature remains neutral with regard to jurisdictional claims in published maps and institutional affiliations.

\section{Authors and Affiliations}

\section{Irit Mevorach ${ }^{1,2}$}

1 Professor of International Commercial Law, University of Nottingham, Nottingham, UK

2 Co-Director, University of Nottingham Commercial Law Centre, Nottingham, UK 